\title{
HOW TO IMPROVE STUDENTS' SCIENCE LEARNING OUTCOME? AN APPLICATION OF PROBLEM-BASED LEARNING WORKSHEETS
}

\author{
Erni $^{1^{*}}$, Yuberti ${ }^{2}$ \\ ${ }^{1}$ PGSD, FKIP, Universitas Lampung \\ ${ }^{2}$ Department of Physics Education, Universitas Islam Negeri Raden Intan Lampung, Indonesia
}

*Corresponding author: dra.ernimpd@gmail.com

\begin{tabular}{|c|c|}
\hline Article Info & ABSTRACT \\
\hline Article history: & The low of learning outcomes is a learning problem that is always \\
\hline $\begin{array}{l}\text { Received: September 03, } \\
2021 \\
\text { Accepted: October 10, } 2021 \\
\text { Published: November 20, } \\
2021\end{array}$ & $\begin{array}{l}\text { encountered in various schools, including in SD (Primary School) } \\
\text { Negeri } 2 \text { Campang Raya. The purpose of this study was to determine } \\
\text { the differences and the effect of the use of problem-based learning } \\
\text { worksheets on the learning outcomes of } 4 \text { th-grade students at SD } \\
\text { Negeri } 2 \text { Campang Raya. The research method used is quasi- } \\
\text { experimental with a nonequivalent control group design. This study } \\
\text { used non-probability sampling with } 30 \text { students in grade } 4 \text { at SD }\end{array}$ \\
\hline Keywords: & $\begin{array}{l}\text { Negeri } 2 \text { Campang Raya as research subjects. Test and non-test } \\
\text { instruments were used to collect research data and analyze data using }\end{array}$ \\
\hline $\begin{array}{l}\text { Learning outcomes } \\
\text { Problem-based learning } \\
\text { Worksheet }\end{array}$ & $\begin{array}{l}\text { t-test and simple linear regression. The results of the study indicate } \\
\text { that there is an influence from the use of problem-based learning } \\
\text { worksheets on the learning outcomes of 4th-grade students at SD } \\
\text { Negeri } 2 \text { Campang Raya. }\end{array}$ \\
\hline
\end{tabular}

\begin{tabular}{|c|c|}
\hline \multicolumn{2}{|c|}{$\begin{array}{l}\text { BAGAIMANA MENINGKATKAN HASIL BELAJAR SAINS } \\
\text { SISWA? PENERAPAN LEMBAR KERJA BERBASIS MASALAH }\end{array}$} \\
\hline & ABSTRAK \\
\hline Kata Kunci: & Masalah rendahnya hasil belajar siswa adalah masalah pembelajaran \\
\hline $\begin{array}{l}\text { Hasil belajar } \\
\text { Problem based learning } \\
\text { LKPD }\end{array}$ & $\begin{array}{l}\text { yang selalu ditemul di berbagal sekolah, termasuk ditan } \mathrm{SD} \text { Neger } 2 \\
\text { Campang Raya. Tujuan penelitian ini adalah untuk mengetahui } \\
\text { perbedaan dan pengaruh penggunaan lembar kerja berbasis problem } \\
\text { based learning terhadap hasil belajar peserta didik kelas } 4 \text { di SD } \\
\text { Negeri } 2 \text { Campang Raya. Metode penelitian yang digunakan adalah } \\
\text { quasi eksperimen dengan nonequivalent control group design. } \\
\text { Penelitian ini menggunakan nonprobability sampling dengan subjek } \\
\text { penelitian sebanyak } 30 \text { peserta didik kelas } 4 \text { di SD Negeri } 2 \\
\text { Campang Raya. Instrumen tes dan non-tes digunakan untuk } \\
\text { mengumpulkan data penelitian dan analisis data menggunakan uji t } \\
\text { dan regresi linear sederhana. Hasil penelitian menunjukkan bahwa } \\
\text { terdapat pengaruh dari penggunaan lembar kerja berbasis problem } \\
\text { based learning terhadap hasil belajar peserta didik kelas } 4 \text { di SD } \\
\text { Negeri } 2 \text { Campang Raya. }\end{array}$ \\
\hline
\end{tabular}

(C) 2021 Unit Riset dan Publikasi Ilmiah FTK UIN Raden Intan Lampung

\section{INTRODUCTION}

The development of science and technology and the high competition for human resources have resulted in rapid progress in all fields, one of which is in the field of education. Education is a form of embodiment of dynamic human culture whose 
development continues because it plays an important role in human life, especially the process of knowledge transfer [1-3]. In the learning process, the main thing that schools expect is the achievement of learning objectives [2]. A good learning process certainly supports good learning outcomes.

Learning outcomes are abilities obtained by children after going through learning activities. More practically, learning outcomes are also intended to reveal students' abilities which are symbolized in scores, as Diansah et al said [3] that learning outcomes are the results of the assessment of students' abilities which are determined in the form of scores after the learning process. The use of scores on certain test results is intended to determine the absorption of students after receiving the lesson [4]. Learning outcomes are the result of a learning interaction that ends with the process of evaluating learning outcomes [5]. From the side of students, learning outcomes are the end of the peak of the learning process.

Based on the results of the 2018 Program for International Students Assessment (PISA) it shows that 70\% of Indonesian students are not able to reach level 2 in the PISA framework [6]. The learning outcomes of Indonesian students are very worrying. Of the 79 countries that participated in PISA, only about 23\% were unable to master level 2 reading skills. The questions at level 2 PISA expect students to be able to determine the main idea in the text, look for relationships between various information in the text, and determine simple conclusions from the text. reading.

Based on the results of preliminary research at SDN 2 Campang Raya, in grade 4 it was found that the 2013 curriculum had been implemented and the learning process in the classroom was in accordance with the lesson plan made by the teacher, however, unfortunately, it has not shown maximum results. Based on observations, the cause of low learning outcomes occurs because the learning process tends to be monotonous and still teacher-centered. This is the major reason that found in many other schools in Indonesia, as explained by Dimyati \& Mudjono [7].

Based on the results of preliminary research, learning at SDN2 Campang Raya has used student worksheets, but not problem-based learning-based worksheets where the components used are only in the form of questions, do not add interesting pictures, and do not contain an explanation of the activities that must be done. done by students. In addition, the teacher seems to give lectures in front of the class so that the learning process tends to be boring which makes students less active in the learning process.

One of the learning models that can be used to improve learning outcomes is the Problem Based Learning (PBL) model. [7-9]. PBL is a learning approach that presents contextual problems so as to stimulate students to learn. The advantages of PBL are that it can improve student learning outcomes, foster student initiative in work, internal motivation to learn, and can develop interpersonal relationships in group work [10]. An alternative solution that can be done is to innovate by using student worksheets that are in accordance with the chosen learning model, namely student worksheets based on problembased learning. The problem-based learning-based worksheet contains the steps for problem-based learning activities.

Astuti et al researched and proved that PBL-based worksheets were able to provide an increase in critical thinking skills with an average N Gain value of 0.824 which was included in the high category [11]. The results of other studies also show that learning using PBL can provide a learning experience in solving problems [12]. Based on the gap from previous research, the researcher will examine the effect of problem-based learning worksheets that are focused on training $\mathrm{C} 1-\mathrm{C} 4$ abilities in order to improve student learning outcomes. This research is important to do to improve the learning outcomes of grade 4 students at SDN 2 Campang Raya in accordance with the demands of the 2013 curriculum. 
Where, problem-based learning worksheets can be used as a means to assist in the teaching and learning process so as to form effective interactions between students and students. educators, in order to improve student learning outcomes.

\section{METHOD}

This type of research is a quasi-experimental with Nonequivalent Control Group Design. The design of this study used two groups, one of which was the experimental group, and the other was the control group. The study then ended with a post-test to both groups. The population in this study were 4th grade students at SDN 2 Campang Raya. Determination of the sample using purposive sampling technique which is a category of non-probability sampling technique. The selected samples were students in class 4-A (experimental) with 29 students, and class 4-B as a control class with 25 students. The procedure in this study can be seen in the following picture.

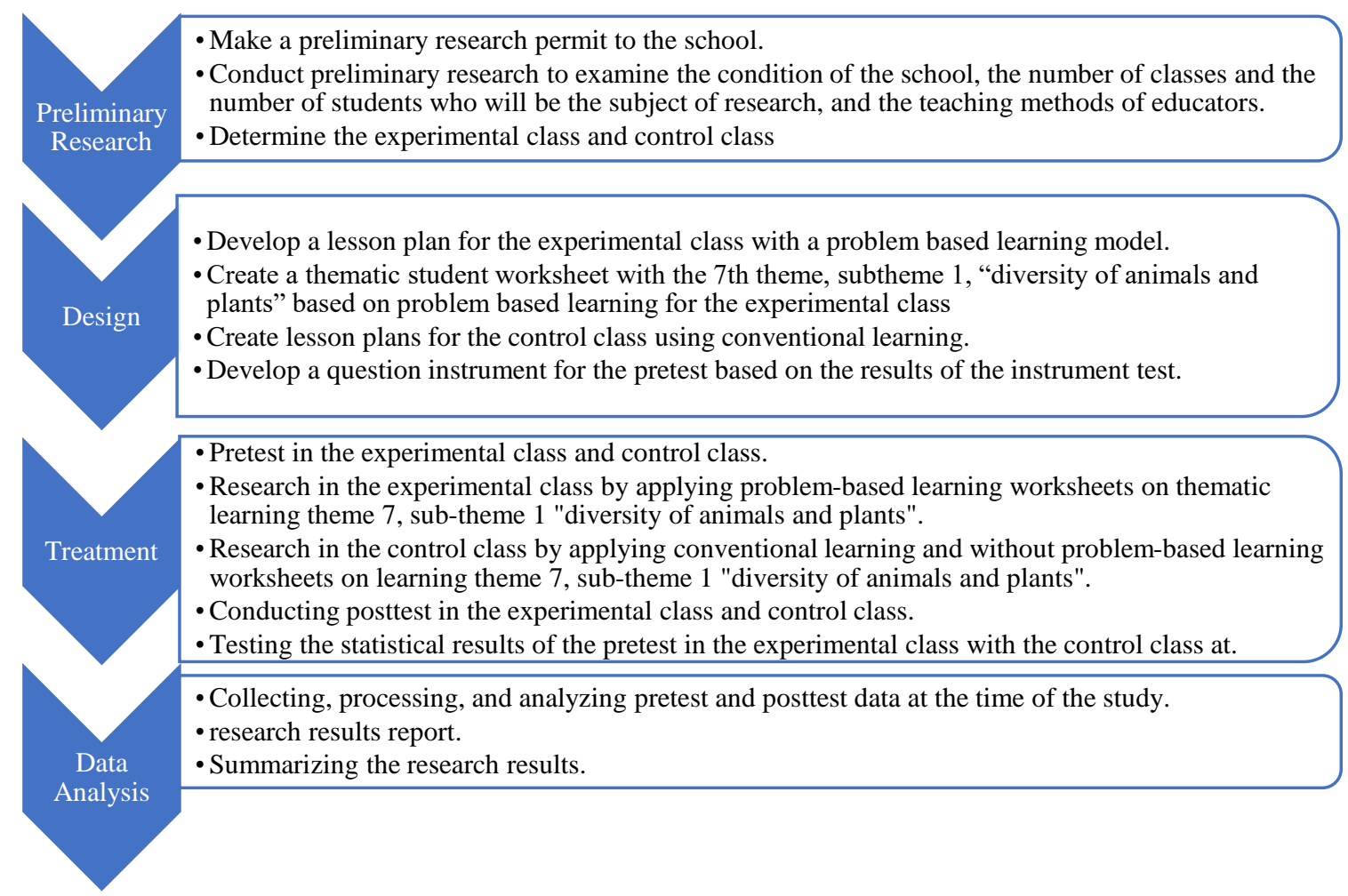

Figure 1. Research Procedure

The test is in the form of pretest and posttest to get data on understanding the concept. The questions used in the pretest are the same as the questions used in the posttest. The form of the test given is an objective test in the form of multiple choice with 30 questions consisting of questions at levels $\mathrm{C} 1-\mathrm{C} 4$. The non-test instrument used is an observation sheet for student activities during the learning process. The hypothesis proposed in this study is: there is an effect from the application of problem-based learning worksheets to improve student learning outcomes.

\section{RESULTS AND DISCUSSION}

This research begins with a preliminary research process to determine the profile of the school, the learning process, and the abilities of the students4. In the learning process in class IVA (experimental class), treatment is carried out by applying problem-based learning worksheets, while in class $4 \mathrm{~B}$ (control class) using conventional learning or 
giving assignments according to the lesson, the material taught is thematic theme 7 subtheme 1 "diversity of animals and plants".

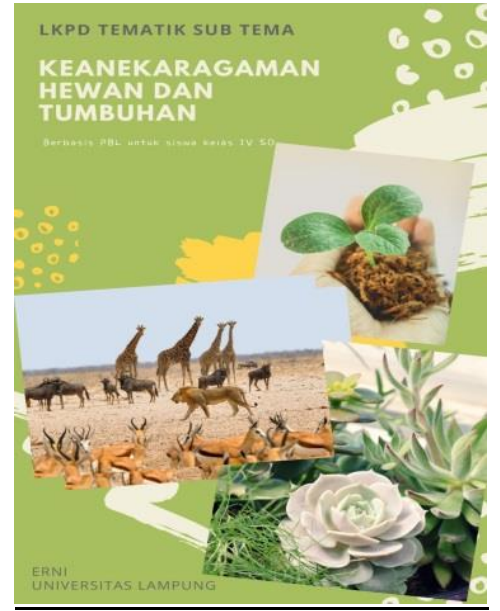

Figure 2. Display of Problem-Based Learning Worksheets

The application of worksheets based on problem based learning in the experimental class was given to 29 students in the experimental class, while 25 students in the control class were not given a worksheet based on problem based learning. The data analyzed is the learning outcomes of students, the data obtained from the cognitive domain pretest scores. Student learning outcomes data are presented in Table 1.

Table 1. Student Posttest Score

\begin{tabular}{ccc}
\hline Learning Approach & N & Mean \\
\hline Experimental Class & 29 & 80,00 \\
Control Class & 25 & 70,00 \\
\hline
\end{tabular}

Based on Table 1, it can be seen that the post-test results of the control class students were 70.00 while the post-test results of the experimental class students were 80.00. Meanwhile, the increase in students' science learning outcomes for the experimental class was in the high category, while the control class was in the medium category. Furthermore, the normality test with a significant level of 0.05 , the results can be seen in the Table 2 .

Table 2. Normality Test Results

\begin{tabular}{ccccc}
\hline No & Class & Lcount & Ltable & Decision \\
\hline 1 & Experimental & 0,143 & 0,164 & $H_{0}$ is accepted \\
2 & Control & 0,169 & 0,177 & $H_{0}$ is accepted \\
\hline
\end{tabular}

Table 2 shows the results of the data normality test with a significant level of $5 \%$. It can be seen that the posttest results of the experimental class are $\mathrm{L}_{\text {count }}=0,143<\mathrm{L}_{\text {table }}$ $=0,164$, and for the control class $\mathrm{L}_{\text {count }}=0,169<\mathrm{L}_{\text {table }}=0,177$. So it can be concluded that the experimental and control classes are normally distributed populations. Furthermore, the results of the homogeneity test calculation are presented in table 3 below.

Table 3. Homogeneity Test Results

\begin{tabular}{cccc}
\hline Class & $\mathbf{F}_{\text {count }}$ & $\mathbf{F}_{\text {table }}$ & Decision \\
\hline $\begin{array}{c}\text { Experimental } \\
\text { Control }\end{array}$ & 0,93 & 1,92 & Homogen \\
\hline
\end{tabular}


Based on Table 3, it can be seen that the results of the homogeneity test of student learning outcomes data are $F_{\text {count }}=0,93<F_{\text {table }}=1,92$. With a significant level of 5\%, it can be concluded that $\mathrm{H}_{0}$ is accepted. Thus it can be concluded that the variance of the two groups (experimental class and control class) is homogeneous. Next, the hypothesis test is carried out using the t-test formula, the results are shown in Table 4.

Table 4. Hypothesis Test Results

\begin{tabular}{cccc}
\hline Class & $\mathbf{t}_{\text {count }}$ & $\mathbf{t}_{\text {table }}$ & Decision \\
\hline $\begin{array}{c}\text { Experimental } \\
\text { Control }\end{array}$ & 2,04 & 1,67 & $H_{0}$ is rejected \\
\hline
\end{tabular}

Based on table 4, it is known that the results of hypothesis testing are $t_{\text {count }}>t_{\text {table, }}$, $2,04>1,67$. Based on the hypothesis test criteria, if $t_{\text {count }}>t_{\text {table }}$ then $H_{1}$ is accepted. This means that this problem-based learning worksheet has an effect on improving the learning outcomes of 4th graders in the thematic lessons of theme 7 sub-theme 1 "diversity of animals and plants".

After testing the hypothesis, to further strengthen the results of the research decisions, an $\mathrm{N}$-gain test was held to find out the improvement in learning outcomes, both in the experimental class and the control class. The results of the $\mathrm{N}$-Gain test can be seen in table 5 below.

Tabel 5. N-Gain Test Results

\begin{tabular}{lcccc}
\hline & \multicolumn{2}{c}{ Control } & \multicolumn{2}{c}{ Experimental } \\
\cline { 2 - 5 } & Pretest & Post-test & Pretest & Postest \\
\hline Mean & 48,00 & 70,00 & 54,00 & 80,00 \\
N-Gain & \multicolumn{2}{c}{0,44} & 0,52 \\
\% Ngain & \multicolumn{2}{c}{$44 \%$} & \multicolumn{2}{c}{$52 \%$} \\
Category & Moderate & Moderate \\
\hline
\end{tabular}

After using problem-based learning worksheets in grade 4 in thematic theme 7 sub-theme 1 "diversity of animals and plants", the value of students increased to 80.00 and student learning outcomes increased by $52 \%$ (moderate improvement category). And in the control class that uses the conventional learning model, the average student score increases to 70.00 , with a percentage increase of $44 \%$ in the medium category.

Based on the research data, it is known that the application of problem-based learning worksheets can affect the learning outcomes of 4th graders at SDN 2 Campang Raya. This is proven by the increase in the scores, at the pre-test, students got low scores and then increased during the posttest. As previous research which explained that worksheet can provoke students to be active in learning, help students to find and develop concepts, train students to find concepts and be responsible for learning, and can develop students' interest in continuing to learn [14]. Another previous research also stated that the use of a worksheet with a PBL approach is effective in improving student learning outcomes [15-16].

Based on the results of the observation sheet assessment, it was also seen that the students seemed enthusiastic in participating in the learning using the worksheet. This shows that the application of problem-based learning worksheets has an effect on student learning outcomes. Students' understanding of the material is quite good because during the learning process, students play an active role in solving problems so that during the posttest students get better scores than the pretest scores. Learning in the experimental class using problem-based learning worksheets went smoothly and the learning outcomes 
were satisfactory because, with this PBL-based worksheet, students had many independent discovery activities that trained students' thinking skills.

\section{CONCLUSION}

Based on the explanation above, it can be concluded that there is an influence from the use of problem-based learning worksheets on the learning outcomes of 4th-grade students at SD Negeri 2 Campang Raya.

\section{REFERENCES}

[1] Anwar, C. (2019). Hakikat Manusia Dalam Pendidikan: Sebuah Tinjauan Filosofis. Yogyakarta: Suka Press.

[2] Diansah, I \& A Asyhari 2020 Evectiveness of Physics Electronik Modules based on self directed learning Model(SDL) towards the understanding of dynamic fluid concept. Jurnal of physics :Confence series 1572012021

[3] Diansah, I . Suyatna, A., \& Viyanti. 2020 STEM-based physics multimedia design for stimulating HOTS on water and wind energy topic: Physics teacher perception. Jurnal of physics :Confence series 1796012002

[4] Namira, Z. B., Kusumo, E., \& Prasetya, A. T. (2014). Keefektifan Strategi Metakognitif Berbantu Advance Organizer Untuk Meningkatkan Hasil Belajar Kimia Siswa. Jurnal Inovasi Pendidikan Kimia, 8(1), 1271-1280.

[5] Achdiyat, Maman dan Rido Utomo. 2017. "Kecerdasan Visual-Spasial, Kemampuan Numerik, dan Prestasi Belajar Matematika". Formatif: Jurnal Ilmiah Pendidikan MIPA 7(3):234-245. doi: 10.30998/formatif.v7i3.2234.

[6] Aisyah, Isnaini dkk. 2017. "Penerapan Model Pembelajaran Numbered Heads Together (NHT) dengan Media Kartu Soal untuk Meningkatkan Keterampilan Sosial dan Prestasi Belajar Sejarah". Jurnal Pendidikan Sejarah Universitas Sebelas Maret.

[7] Dimyati \& Mudjiono. 2013. Belajar Dan Pembelajaran. Jakarta: Rineka Cipta.

[8] Malaysian Qualification Agency. (2016). Programme Standar Education. MQA. Slangor.[ONLINE] http://www/nbpts.org diakses pada tanggal 10 Oktober 2019. Pada pukul 21.30 WIB

[9] Yuberti (2015). Online Group Discussion pada Mata Kuliah Teknologi Pembelajaran Fisika. Jurnal Ilmiah Pendidikan Fisika Al-Biruni, 4(2), 145. https://doi.org/10.24042/jpifalbiruni.v4i2.88

[10] Pratiwi, A, Z. B., Maria, H.T., \& Sirait, J. (2016). Penggunaan Model PBL Untuk Meningkatkan Hasil Belajar Pada Materi Perubahan Wujud Zat di SMP. Jurnal Pendidikan Dan Pemebelajaran Khatulistiwa, 5(3),

[11] Hadi, Fida R (2016). Penerapan Pembelajaran Problem Based Learning (PBL) Untuk Meningkatkan Hasil Belajar Matematika Siswa Kelas IV Sekolah Dasar. Jurnal Profesi Pendidikan Dasar, 3(2),84-91

[12] Hikmah, Milhatul (2020). Penerapan Model Project Based Learning Untukmeningkatkan Partisipasi Dan Hasil Belajar Pemrograman Dasar Siswa. Jurnal teknodik, 24(1),25-35

[13] Astuti, Sri., Danial. M., Anwar. M, (2018). Pengembangan LKPD Berbasis PBL (Problem Based Learning) Untuk Meningkatkan Keterampilan Berpikir Kritis Peserta Didik Pada Materi Kesetimbangan Kimia. Jurnal Pendidikan kimi, 2 (2), 25 35

[14] Yustianingsih.H, Syarifuddin. H., Yerizon (2017). Pengembangan Perangkat Pembelajaran Matematika Berbasis Problem Based Learning(PBL) untuk 
meningkatkan kemampuan pemecahan masalah peserta didik kelas VIII, Jurnal Nasional Pendidikan Matematika JNPM, 1(2)

[15] Setyosari, P. (2012) Metode Penelitian Pendidikan dan Pengembangan. Jakarta: Kencana.

[16]Trianto. (2011). Model-model Pembelajaran Inovatif Berorientasi Konstruktivistik. Jakarta: Prestasi Pustaka

[17] Riski, W., Nurmaliyah, C., \& M, Ali. S. (2016). Pemanfaatan Lembar Kerja Peserta Didik (LKPD) Berbasis Problem Based Learning (PBL) Terhadap Peningkatan Hasil Belajar Siswa Pada Materi Sistem Ekskresi Manusia Di Mtsn Rukoh Kota Banda Aceh. Jurnal Biotik, 4(2), 136-142

[18] Zaturahmi, Adlim., \& Zulkarnaen. (2016). Pengembangan Lembar Kerja Peserta Didik (LKPD) Berbasis masalah bahasan cermin untuk Peningkatan motivasi belajar dan Hasil Belajar Siswa di SMP Negeri 2 Banda Aceh. Jurnal pendidikan sainsa indonesia, 4(2), 162-170 